\title{
Zircon record of fractionation, hydrous partial melting and thermal gradients at different depths in oceanic crust (ODP Site 735B, South-West Indian Ocean)
}

\author{
A. Pietranik ${ }^{1}$ C. Storey ${ }^{2}$ J. Koepke ${ }^{3} \cdot$ S. Lasalle ${ }^{2,4} \cdot$ EIMF
}

Received: 22 June 2016 / Accepted: 16 December 2016 / Published online: 14 February 2017

(C) The Author(s) 2017. This article is published with open access at Springerlink.com

\begin{abstract}
Felsic veins (plagiogranites) are distributed throughout the whole oceanic crust section and offer insight into late-magmatic/high temperature hydrothermal processes within the oceanic crust. Despite constituting only $0.5 \%$ of the oceanic crust section drilled in IODP Site 735B, they carry a significant budget of incompatible elements, which they redistribute within the crust. Such melts are saturated in accessory minerals, such as zircon, titanite and apatite, and often zircon is the only remaining phase that preserves magmatic composition and records processes of felsic melt formation and evolution. In this study, we analysed zircon from four depths in IODP Site 735B; they come from the oxide gabbro (depth approximately $250 \mathrm{~m}$ below sea floor) and plagiogranite (depths c. 500, 860, $940 \mathrm{~m}$ below sea floor). All zircons have similar $\varepsilon \mathrm{Hf}$ composition of c. 15 units indicating an isotopically homogenous source for the mafic magmas forming IODP
\end{abstract}

Communicated by Gordon Moore.

Electronic supplementary material The online version of this article (doi:10.1007/s00410-016-1324-y) contains supplementary material, which is available to authorized users.

\section{A. Pietranik}

anna.pietranik@uwr.edu.pl

1 Institute of Geological Sciences, University of Wroclaw, Wroclaw, Poland

2 School of Earth \& Environmental Sciences, University of Portsmouth, Portsmouth, UK

3 Institut für Mineralogie, Leibniz Universität Hannover, Hannover, Germany

4 EIMF - Edinburgh Ion Micro-Probe Facility, The School of GeoSciences, The University of Edinburgh, Edinburgh, UK
Site 735B gabbro. Zircons from oxide gabbro are scarce and variable in composition consistent with their crystallization from melts formed by both fractionation of mafic magmas and hydrous remelting of gabbro cumulate. On the other hand, zircon from plagiogranite is abundant and each sample is characterized by compositional trends consistent with crystallization of zircon in an evolving melt. However, the trends are different between the plagiogranite at $500 \mathrm{~m}$ bsf and the deeper sections, which are interpreted as the record of plagiogranite formation by two processes: remelting of gabbro cumulate at $500 \mathrm{~m}$ bsf and fractionation at deeper sections. Zircon from both oxide gabbro and plagiogranite has $\delta^{18} \mathrm{O}$ from 3.5 to $6.0 \%$. Values of $\delta^{18} \mathrm{O}$ are best explained by redistribution of $\delta^{18} \mathrm{O}$ in a thermal gradient and not by remelting of hydrothermally altered crust. Tentatively, it is suggested that fractionation could be an older episode contemporaneous with gabbro crystallization and remelting could be a younger one, triggered by deformation and uplift of the crustal pile.

Keywords Oceanic crust - Felsic melt · Zircon crystallization - Fractionation $\cdot$ Hydrous melting $\cdot$ Trace elements $\cdot \mathrm{Hf}$, $\mathrm{O}$ isotopes

\section{Introduction}

Oceanic crust constitutes approximately $60 \%$ of the Earth's crust and its continuous formation at ocean ridges depletes underlying mantle in incompatible elements. The elements are later distributed within the oceanic crust by magmatic and hydrothermal processes. The lower oceanic crust comprises predominately mafic to ultramafic rocks evolving in a general framework of fractional crystallisation, crystal accumulation and intercumulus melt removal (e.g., Klein 
2003; Coogan 2014). While oceanic crust formed at fastspreading rates exhibits a relatively uniform seismic stratigraphy (e.g. Canales et al. 2003) and is regarded as layered and relatively homogeneous, oceanic crust generated at slow-spreading ridges is characterized by larger heterogeneity. Here, crustal accretion is dominated by tectonic rather than solely by magmatic processes (e.g. Cannat 1996; Dick et al. 2006). Also, typical oceanic crust sections from slow-spreading ridges are constructed from numerous magma pulses evolving separately, without the presence of long-lived axial magma lenses, as characteristic for fastspreading ridges (e.g. Dick et al. 2000). The late stage of magmatic evolution of oceanic crust, either after or contemporaneous with the extraction of basaltic melts from the cumulate pile, involves formation of diorites, quartz-diorites, tonalites and trondhjemites, collectively termed "oceanic plagiogranites" (for definition see Koepke et al. 2007). The consensus is that the felsic lithologies crystallized from evolved melts at temperatures above $800^{\circ} \mathrm{C}$ (e.g. Robinson et al. 2002). They carry a significant budget of incompatible trace elements (e.g. Godard et al. 2009), and as they travel upwards, they redistribute these elements throughout the oceanic crust.

Therefore, plagiogranite evolution affects the mobility and distribution of the incompatible elements within the oceanic crust during the magmatic stage but possibly also during later interaction of the crust with seawater and finally in subduction zones and in the mantle, where the subducted crust is partially melted. The interaction between the oceanic crust and seawater has a significant effect and is best illustrated by the change in oxygen isotope composition through the oceanic crust section. In a typical profile, the crust is altered with $\delta^{18} \mathrm{O}$ values up to $13 \%$ in the volcanic part of the crust and $\delta^{18} \mathrm{O}$ down to $4 \%$ in the plutonic part of the crust (e.g. Gregory and Taylor 1981). This is respectively higher and lower than approximately $5.6 \%$, a value typical for unaltered basalt. The alteration is also observed in plagiogranites as most of the major mineral assemblages in plagiogranite veins are strongly hydrothermally altered (Robinson et al. 2002), and it is, therefore, difficult to reconstruct the magmatic stage of plagiogranite crystallization based on major minerals or whole rock geochemistry. However, zircon remains often unaltered and is a suitable phase in the felsic veins that records the magmatic evolution of the crust and offers insight into late stages of oceanic crust development. In particular, zircon isotope and trace element composition may contribute to the on-going debate on the origin of felsic melts in oceanic crust and constrain their origins as extremely fractionated mafic melts versus melts formed by hydrous remelting of cumulate gabbros (e.g. Koepke et al. 2004; Brophy 2009). Previous $\mathrm{O}$ isotope analyses of oceanic zircon showed uniform $\delta^{18} \mathrm{O}$ values around 5.7\%o, which was not interpreted in terms of possible plagiogranite formation processes. On the other hand, $\mathrm{O}$ isotope analyses in zircon from ophiolitic plagiogranites ranged from 3.9 to $5.6 \%$, which is consistent with remelting of altered oceanic crust to produce the felsic melts (Grimes et al. 2013).

Site 735B offers unparalleled insight into in situ oceanic crust formed at ultra-slow ridges. Tectonic processes uplifted the plutonic section of the crust and ODP Leg 176 drilling recovered approximately $1500 \mathrm{~m}$ of mostly gabbroic rocks. In this study, we present zircon compositions from four depth levels in Site 735B and interpret them in the context of related oxide gabbro and plagiogranite formation. We also show that the zircons record contrasting processes of the felsic melts' formation, with the upper part of Site 735B being dominated by felsic veins produced possibly by hydrous partial melting of gabbro and the lower part dominated by felsic veins formed by extreme fractional crystallization of MORB. We demonstrate that zircon is a particularly useful tool that offers insight into oceanic crust development at the interface between late-magmatic and post-magmatic metamorphic processes; a regime where the petrological record is mostly obscured by later low temperature hydrothermal alteration.

\section{Analytical methods}

Zircons were separated from core pieces (usually quarter of the core section or less and a few $\mathrm{cm}$ long). One or several core pieces from similar depths were crushed together in a jaw crusher and then the crushed material was sieved. Next, the divided material was carefully panned and examined under a binocular microscope, the zircons were picked using tweezers and mounted in epoxy resin. Once polished to reveal the interiors of the grains, the zircons were imaged by charge contrast in a Scanning Electron Microscope (SEM) at the University of Bristol. Then the zircons were analysed for $\mathrm{O}$, Hf and major and trace elements. Detailed description of the analytical procedures is given in Appendix 1. Full data sets are given in Appendices 2 to 5 (Appendix 2: O isotope data, Appendix 3: Hf isotope data, Appendix 4: trace element data by LA-ICPMS (Laser Ablation-Inductively Coupled Plasma Mass Spectrometry), Appendix 5: microprobe data). Oxygen isotopes were analysed using a CAMECA IMS 1270 secondary ionisation mass spectrometer (SIMS) at the University of Edinbourgh. Hafnium isotopes were analysed using a Thermo-Scientific Neptune MC-ICPMS (Multi CollectorInductively Coupled Plasma Mass Spectrometer) coupled to a New Wave Research UP193HE Deep-UV (193 nm) ArF Excimer laser ablation sampling system at the University of Bristol (Bristol Isotope Group). Major elements: $\mathrm{Zr}$, $\mathrm{Si}, \mathrm{Hf}, \mathrm{P}$ and $\mathrm{Y}$ were analysed using an electron microprobe (EPMA) CAMECA SX100 at the University of Warsaw. 
The analytical conditions were: $60 \mathrm{nA}$ beam current, $15 \mathrm{kV}$ voltage and focused beam. Trace elements were analysed using Laser Ablation-Inductively Coupled Plasma Mass Spectrometer (LA-ICPMS: Asi Resolution ArF $193 \mathrm{~nm}$ laser coupled to an Agilent 7500CS quadrupole mass spectrometer) at the School Of Earth and Environmental Sciences at the University of Portsmouth. Trace elements were analysed twice with the first attempt, at a different laboratory resulting in failure; only the second attempt at the University of Portsmouth was successful. The first attempt left 70 micron holes in many zircon grains.

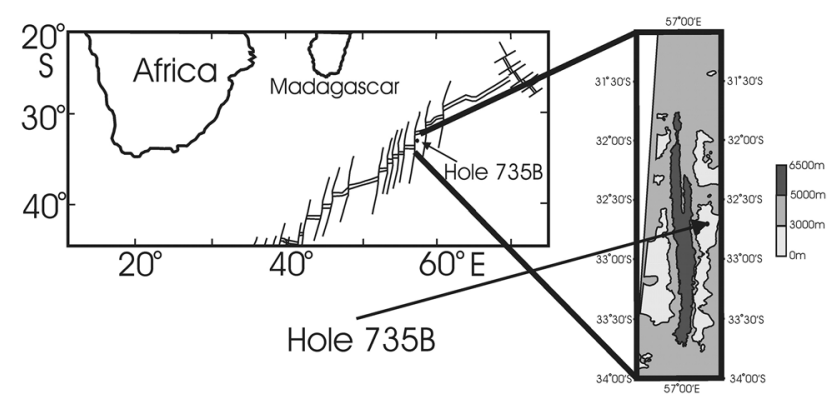

Fig. 1 a Location of Hole 735B and b Bathymetric map of the Atlantis II Fracture Zone modified from Dick et al. (1991)

\section{Site 735B-petrography and geochemistry}

Site 735B is located at the Atlantis II Transform Fault (Fig. 1) on the ultra-slow-spreading Southwest Indian Ridge with spreading rate estimated at $16 \mathrm{~mm}$ /year (Fisher and Sclater 1983). Site 735B is situated on the Atlantis Bank, which is a flat, uplifted block of the seafloor currently residing $720 \mathrm{~m}$ below sea level (Natland and Dick 2002a). The drilling had a total depth of $1508 \mathrm{~m}$ and was completed during two legs: Leg 118 in 1987 and Leg 176 in 1997. Over $860 \mathrm{~m}$ of igneous rock was recovered during the second leg, which represents $86 \%$ recovery (Natland and Dick 2002b).

The Hole735B drillcore is represented predominately by olivine gabbro (over 76\%) and oxide gabbro (approximately $24 \%$ vol., Natland and Dick 2002a; Hertogen et al. 2002) The olivine gabbro was divided into three sections with boundaries at approximately $250 \mathrm{~m}$ b.s.f. (below sea floor) and $500 \mathrm{~m}$ b.s.f. The uppermost two are more primitive as illustrated by their higher $\mathrm{Mg} /\left(\mathrm{Mg}+\mathrm{Fe}^{2+}\right)$ ratios and lower $\mathrm{TiO}_{2}$ wt $\%$ than those in the third section (Natland and Dick 2001). They are separated by an approximately $50 \mathrm{~m}$ thick zone of massive oxide gabbro, the thickest horizon of oxide gabbro in Hole 735B (Fig. 2a). Oxide gabbros are distributed through the olivine gabbro suite in all three sections with sharp contacts between the two lithologies (Ozawa et al. 1991). The oxide gabbros have higher $\mathrm{TiO}_{2}$ concentration in whole rock and generally lower An content

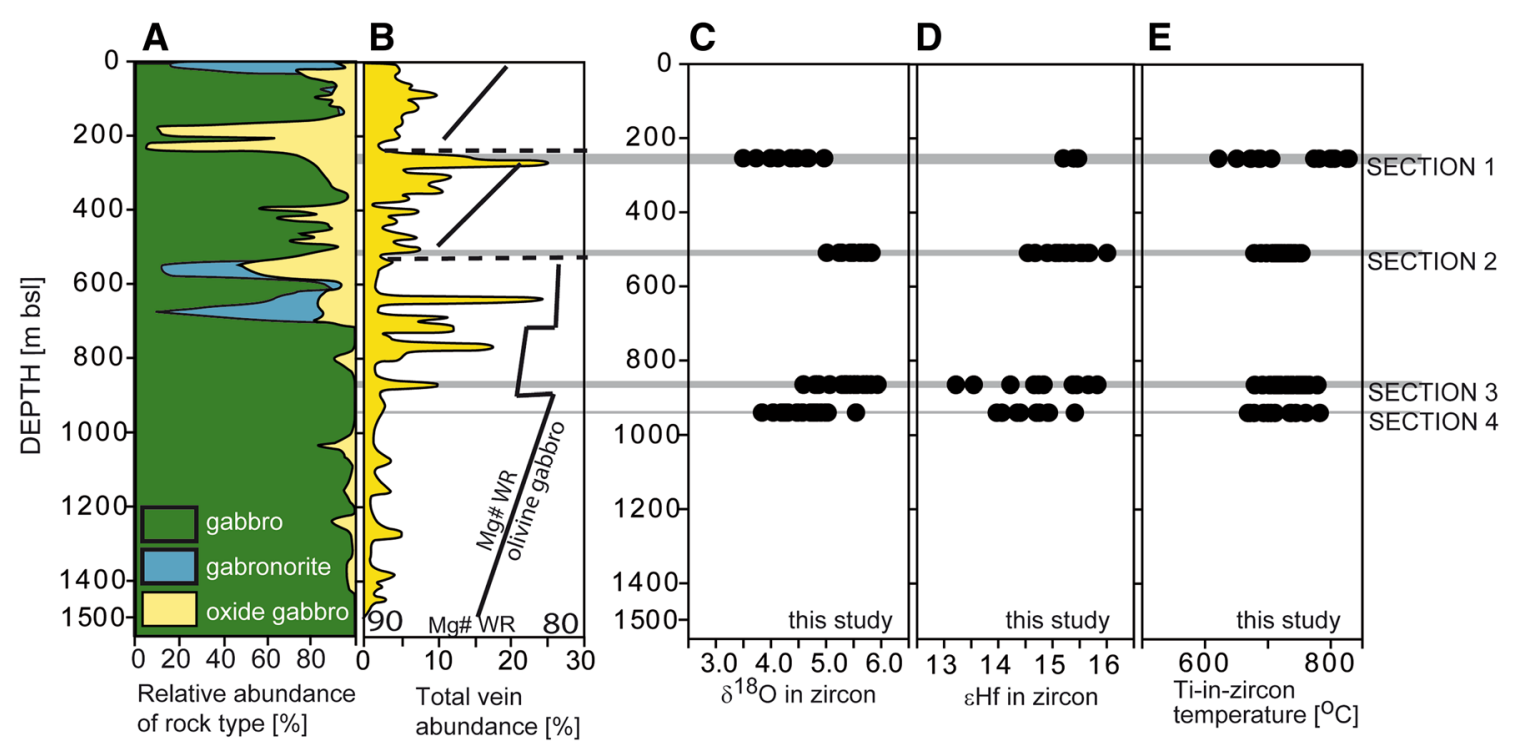

Fig. 2 Sampling sections (grey bands representing the range of depths from which the analysed samples were taken) related to the downhole logs from Site 735B showing a abundances of major rock types, modified after Dick et al. (1999), the profile was simplified such that gabbro comprises troctolitic gabbro, olivine gabbro and gabbro and oxide gabbro comprises disseminated Fe-Ti oxide gabbro, $\mathrm{Fe}-\mathrm{Ti}$ oxide gabbronorite and $\mathrm{Fe}-\mathrm{Ti}$ oxide gabbro, b relative abun- dance of felsic veins modified after Robinson et al. (2002) and $\mathrm{Mg}$ number in primitive gabbro modified after Natland and Dick (2002a). The remaining profiles show data obtained in this study c-d) $\delta^{18} \mathrm{O}$ and $\varepsilon \mathrm{Hf}$ in the whole zircon populations analysed in different sections and e uncorrected Ti-in-zircon temperature in different sections, calculated using the calibration from Watson et al. (2006) 
in plagioclase and $\mathrm{Mg} /(\mathrm{Mg}+\mathrm{Fe})$ in olivine and pyroxene compared to olivine gabbros (Ozawa et al. 1991). The oxide gabbros are also characterized by disequilibrium between Fe-Ti oxides and major minerals as well as alignment of the oxides along shear zones (Dick et al. 2000; Niu et al. 2002). These together point to complex origins of oxide gabbros and suggest that they may contain, beside typical cumulate minerals, significant amounts of liquid expelled from the crystallizing olivine gabbros (Dick et al. 2000).

Felsic veins (plagiogranite) constitute approximately $0.5 \%$ volume of Site 735B (Niu et al. 2002; Robinson et al. 2002). The veins are up to several centimetre thick and have predominately leucodiorite composition (Robinson et al. 2002). Interestingly, they are distributed throughout the whole of Hole735B section suggesting that their distribution could be controlled by late shearing and melt expulsion (Dick et al. 2000).

\section{Samples}

Zircon was separated from drill cores from four depth intervals as shown in Table 1. The intervals are called Section 1 to 4 in the following paper.

The samples from Section 1 are all located in oxide gabbro (classified as interstitial olivine bearing oxide gabbro or olivine Fe-Ti oxide microgabbro according to Ozawa et al. 1991). They belong to the massive $55 \mathrm{~m}$ oxide gabbro section emplaced between two olivine gabbro sections (Natland and Dick 2002a). The oxide gabbro horizon is also divided into several parts (Ozawa et al. 1991). The zircon was taken from the part which is strongly differentiated and characterized by evolution towards the lowest An in plagioclase and the lowest $\mathrm{Mg} /(\mathrm{Mg}+\mathrm{Fe})$ in olivine and clinopyroxene from the top to the bottom of the oxide gabbro section (Section IV of the oxide gabbro from Ozawa et al. 1991).

The samples from Sections 2 to 4 all contain felsic veins. The samples from Section 2 comprise a single $3-\mathrm{cm}$ thick felsic vein in olivine gabbro and the samples from Section 3 comprise a single felsic $1.5-\mathrm{cm}$ thick vein and Section 4 includes multiple thin felsic veins. All the veins in the Sections 3 and 4 are located within olivine gabbro. In samples with thin veins whole samples (1/4 core sections) were crushed, sieved and panned in search for the zircon grains. However, we believe that zircon comes from the veins since the samples composed entirely of olivine gabbro did not yield a single zircon grain.

\section{Zircon: structure, chemical and isotope composition}

Section 1 (248-265 m b.s.f.): Only seven zircon grains were found in the Section 1 samples. The zircon grains are $100-150 \mu \mathrm{m}$ in diameter along their $z$ axes. They can be classified as Type 2 grains according to Grimes et al. (2009), i.e. subhedral grains showing magmatic, oscillatory and/or sector zoning (Fig. 3). The zircon grains can be divided into three groups based on their composition, each group is located in its own compositional field for many trace elements (Fig. 4). Despite the chemical variability, all of the zircons have typical magmatic REE patterns. Group 1 comprises two grains, which are bright in the contrast images. The Group 1 zircon has the highest $\mathrm{Ti}$ and lowest $\mathrm{U}$ contents. The Ti content is from 16 to $25 \mathrm{ppm}$, and therefore, is the highest from all analysed grains in Site 735B. Group 2 comprises four grains (three analysed by LA-ICPMS and all four by EPMA). The grains have dark charge contrast cores and lighter rims. They have the lowest Ti, Hf, Nb, Ce, P, LREE, MREE and Ta contents compared to all other grains from Section 1. The zircons are also characterized by the least negative Eu anomaly, lowest $\mathrm{Th} / \mathrm{U}$ and highest HREE/MREE and HREE/LREE. Interestingly, zircons with composition similar to those in Group 2 were not observed in the database of Grimes et al. (2009), in particular because of their pronounced Eu anomaly. Group 3 is represented by a single grain, which has the highest Hf, U, Th, P, Y, REE (minus Eu), Nb, Ta contents and moderate Ti contents. The grain also has the most negative Eu anomaly. High Hf, $\mathrm{Y}$ and $\mathrm{P}$ contents in the grain were confirmed by EPMA (Table SM5). The high concentrations of $\mathrm{U}, \mathrm{Th}, \mathrm{P}, \mathrm{Y}, \mathrm{REE}, \mathrm{Nb}, \mathrm{Ta}$ are similar to those of some grains from leucocratic veins analysed in Section 3; however, the grain has higher Hf concentration. Similar

Table 1 Characteristic of Sections 1 to 4 as defined in this study

\begin{tabular}{|c|c|c|c|}
\hline & Depth [m b.s.f.] & Lithology & Sample names \\
\hline Section 1 & $248-265$ & Oxide gabbro & $\begin{array}{l}\text { 118-0735B-052R-04W-47-51; 118-0735B-053R-03W-131-135; } \\
\text { 118-0735B-053R-04W-28-32; 118-0735B-053R-05W-47-54; } \\
\text { 118-0735B-054R-02W-35-44 }\end{array}$ \\
\hline Section 2 & $506-513$ & Plagiogranite & 176-0735B-090R-01W-38-46 and 176-0735B-090R-01W-61-67 \\
\hline Section 3 & $859-870$ & Plagiogranite & 176-0735B-138R-04W-54-58 \\
\hline Section 4 & 940 & Plagiogranite & 176-0735B-146R-01W-61-64; 176-0735B-146R-01W-74-78 \\
\hline
\end{tabular}

Sample names are original names given by the ODP Leg 176 Scientific Party 

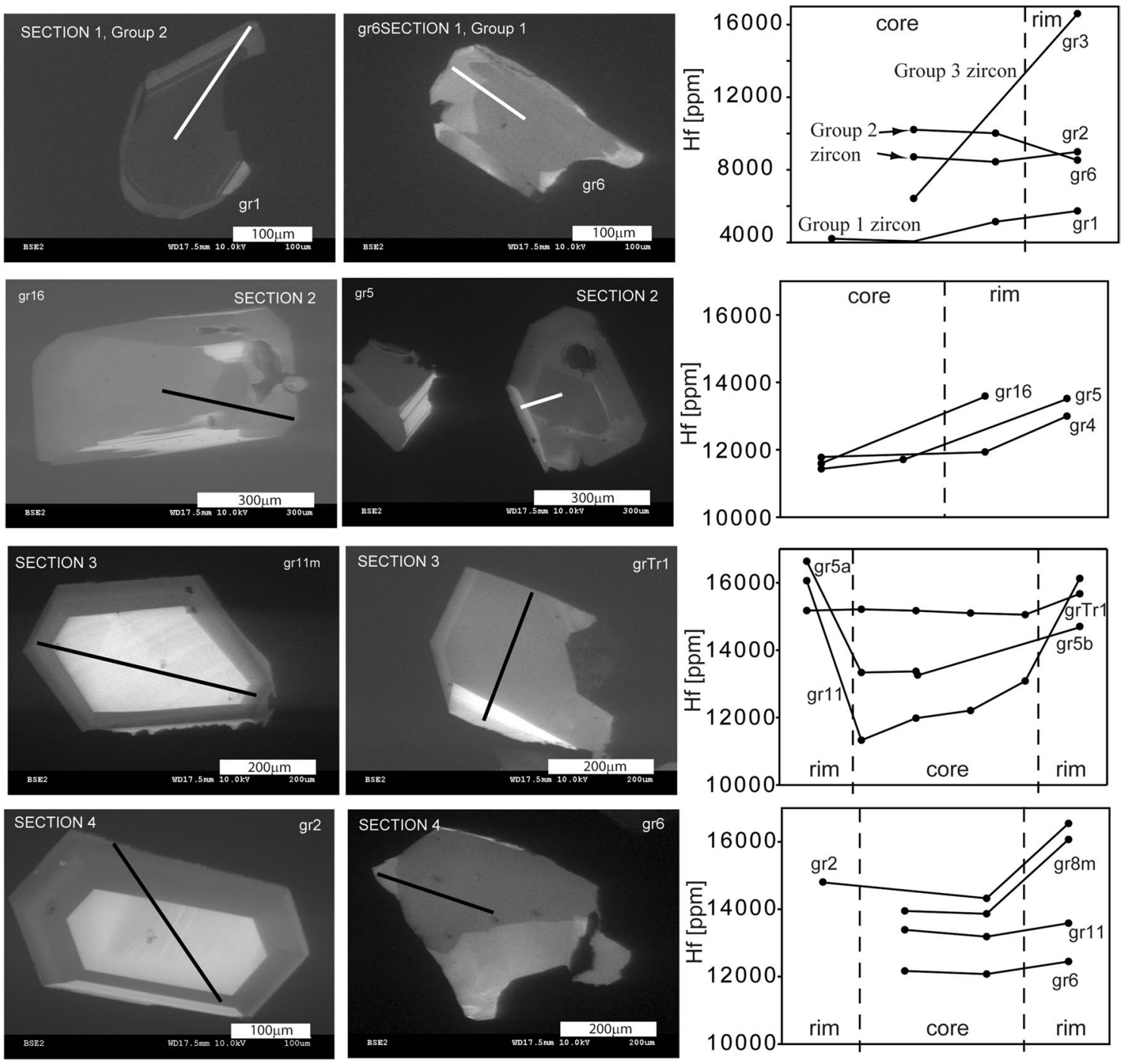

Fig. 3 Charge contrast images of representative zircon grains from different depth sections and the corresponding Hf concentrations. The points are evenly spaced along the shown traverses

grains were analysed and are included in the databases of Grimes et al. (2009). O isotopes varied slightly between groups (Fig. 5) and $\delta^{18} \mathrm{O}$ was the highest in Group 1 zircon (from 4.0 to $5.0 \%$ ), slightly lower in Group 2 (from 3.7 to $4.4 \% o$ ) and the Group 3 grain had $\delta^{18} \mathrm{O}$ of $3.5 \%$. Hf isotopes were uniform with $\varepsilon \mathrm{Hf}$ from 15.2 to 15.5 (Fig. 2).

Section 2 (506-513 m b.s.f.): Zircons from this section are the most uniform in trace element composition from all of the sections. The zircon grains are $100-500 \mu \mathrm{m}$ in diameter along their $z$ axes, and are subhedral to euhedral. They have concentric or sector zoning. Larger grains have dark cores in contrast images surrounded by lighter mantles and then darker rims (Fig. 3). Elongate, highly luminescent zones occur close to the zircon rims, usually along one of the zircon faces. The luminescent parts are not characterized by clearly distinct compositions compared to other parts of zircon grains. Larger zircon grains are zoned from cores to rims and have enrichment in most of the elements, particularly $\mathrm{P}, \mathrm{Nb}, \mathrm{Ta}, \mathrm{REE}, \mathrm{U}$ and Th (but not Ti, which is similar throughout the grain). The rims also have slightly higher $\mathrm{Hf}$ contents and are characterized by a more pronounced negative Eu anomaly. One small grain was analysed by EPMA that had much higher $\mathrm{P}$ and $\mathrm{Y}$ than the remaining grains, but similar Hf. In fact, its $\mathrm{P}$ and $\mathrm{Y}$ contents are similar to the Group 3 grain from Section 1. Oxygen and $\mathrm{Hf}$ isotopes are uniform in the whole section and the observed variations are mostly within the analytical uncertainty; $\delta^{18} \mathrm{O}$ varies from 4.7 to $5.8 \%$ (Figs. 2, 5) and $\varepsilon$ Hf has values from 14.6 to 16.0 (Fig. 2).

Sections 3 and 4 (860-940 m b.s.f.): The zircons from both sections have a similar appearance and range of trace element contents. These sections have large variations in 

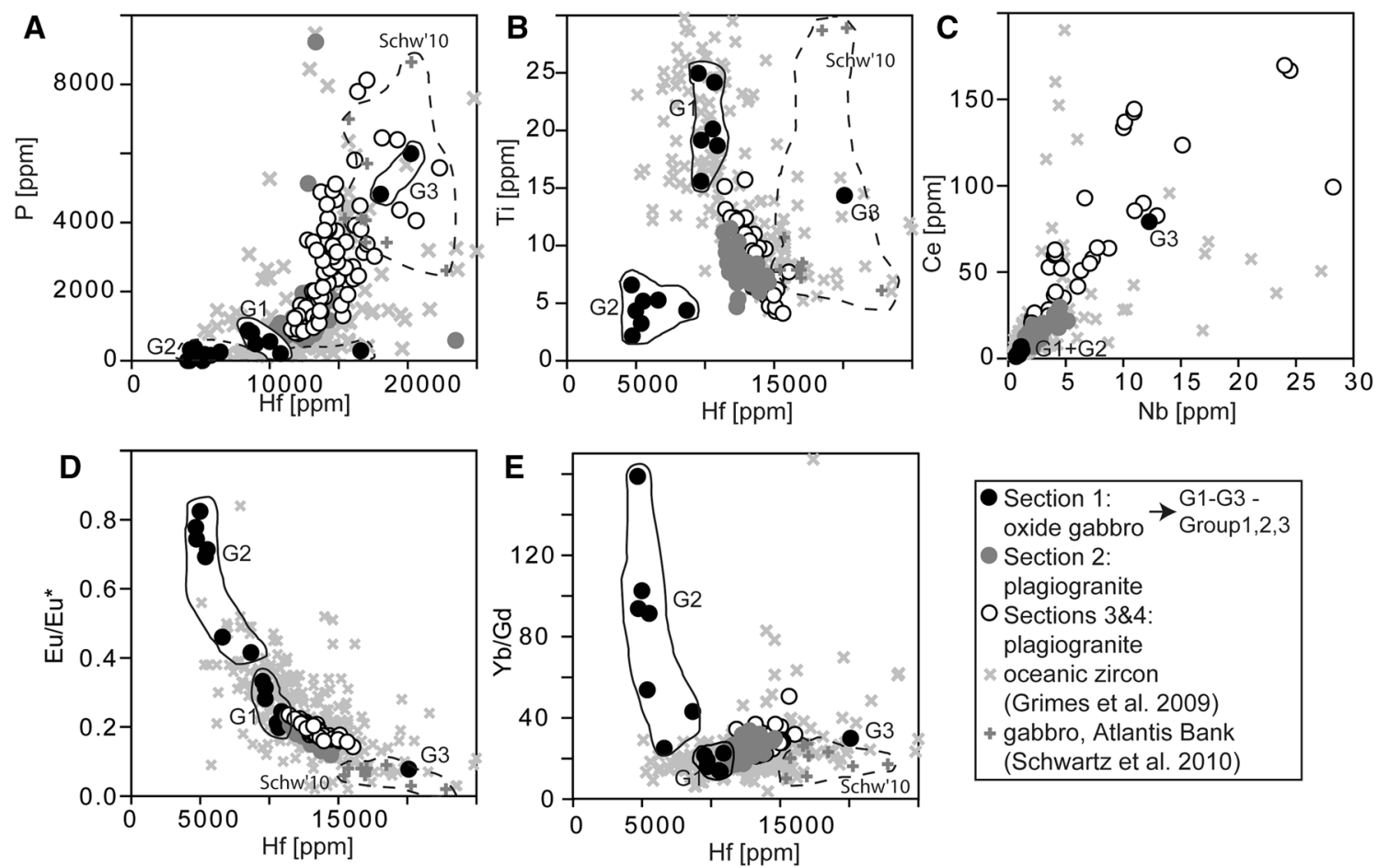

Fig. 4 Distinct compositional groups at different depths of the oceanic crust. Circles this study, Crosses literature database. Three groups from Section 1 are outlined in case their composition is substantially different. Light grey crosses show zircon composition from a wide variety of oceanic gabbro lithologies from three differ- ent localities including Mid-Atlantic Ridge (Holes 1275D, 1270D, 1309B, 1309D and Kane core complexes) and Southwest Indian Ridge (Hole 735B). Dark grey crosses represent zircon from the sample JR-31 29-2, collected by dredging during RRS James Clark Ross Leg 31 (Schwartz et al. 2010)

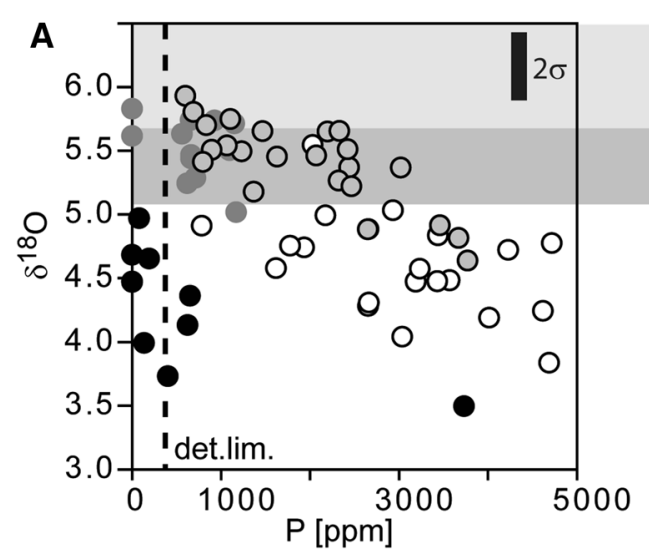

Fig. 5 Variations of $\delta^{18} \mathrm{O}$ with elemental abundances in zircon from different depths. The range typical for $\delta^{18} \mathrm{O}$ values in zircon in equilibrium with mantle melts is after Valley et al. (2005), the range of $\delta^{18} \mathrm{O}$ expected in differentiating MORB is estimated from the equation $\delta^{18} \mathrm{O}=0.052 * \mathrm{SiO}_{2 \mathrm{WR}}+3.03$ (Spulber and Rutherford 1983) and the range of $\mathrm{SiO}_{2}$ is taken from Robinson et al. (2002)

have irregular sector zoning. Differences in trace element contents occur between grains and in a single grain in the core to rim direction. Generally, $\mathrm{Hf}$ increases and $\mathrm{Ti}$ and Eu anomaly decreases in the core to rim direction and these parameters correlate with each other for the whole zircon population (Fig. 4). Other elements, e.g. REE, Nb, U, Th, 

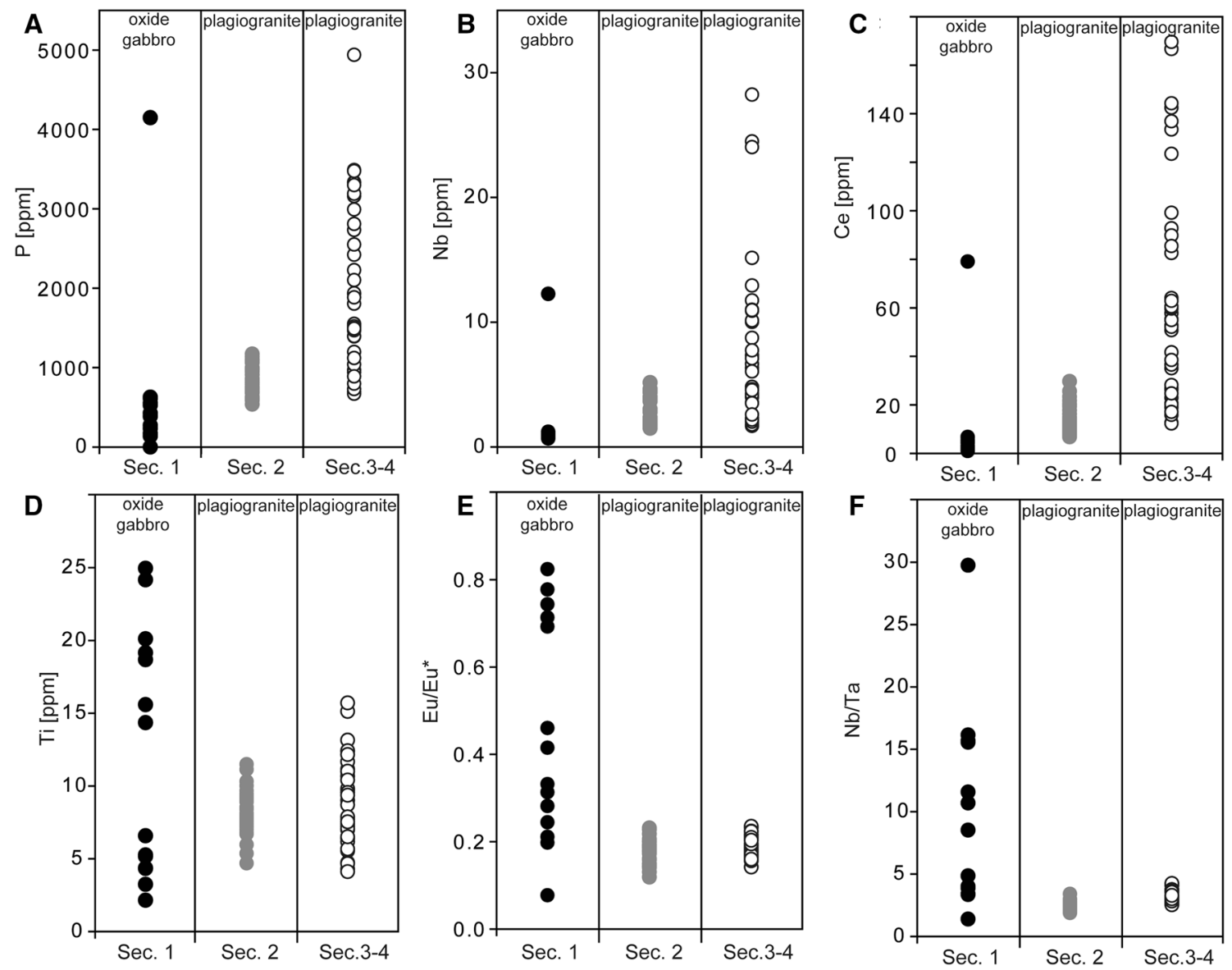

Fig. 6 Comparison of elemental concentrations and ratios between different sections. The single analysis in the oxide gabbro column with high elemental concentrations in A, B and C graphs belongs to Group 3

have complex trends with increasing Hf, i.e. their concentrations increase with $\mathrm{Hf}$ with the maximum values and the large range of concentrations observed at $\mathrm{Hf}=14,000 \mathrm{ppm}$; at $\mathrm{Hf}$ contents $>14,000 \mathrm{ppm}$ they decrease (Fig. 7). The grains with highest contents of $\mathrm{P}, \mathrm{Y}, \mathrm{U}, \mathrm{Th}$ and REE are similar to the grain from Group 3 in Section 1 and the other single grain from Section 2. Generally, Section 3 has more grains with elevated trace element contents and also contains the grain with the highest concentrations of $\mathrm{P}, \mathrm{Y}, \mathrm{U}$, Th and REE compared to other sections. Section 3 zircons have $\delta^{18} \mathrm{O}$ ranging from 3.8 to $5.5 \%$, whereas Section 4 zircons range from 4.6 to $5.9 \%$ (Figs. 2, 5). The $\delta^{18} \mathrm{O}$ decreases with increasing $\mathrm{P}$ content in the whole of the zircon population of Sections 3 and $4\left(R^{2}=0.5\right.$ for EPMA dataset). Section 3 has an $\varepsilon \mathrm{Hf}$ range from 14.2 to 15.9 and Section 4 from 13.9 to 15.4 (Fig. 2).

\section{Zircon: comparison between the sections}

Section 1" zircons do not have any clear trends in Hf versus other trace elements, the values are rather scattered or constant for Groups 1 and 2 depending on the element (Figs. 4, 7). The only consistent trend seems to be rapid decrease in Eu anomaly with increasing Hf (Fig. 4).

The zircons from Section 2-4 are from plagiogranite and have overlapping compositions for many of the trace elements. However, Sections 3 and 4 are characterized by higher variability in trace element contents compared to Section 2 and generally higher maximum concentrations of all trace elements except Ti and Hf (Figs. 4, 6). In contrast, many elemental ratios such as HREE/LREE, HREE/ MREE, Eu anomaly and $\mathrm{Nb} / \mathrm{Ta}$ have similar ranges and low variability in all three sections (Fig. 6). Sections 3 and 4 have higher $\mathrm{Th} / \mathrm{U}$ ratios and Ce/other REE ratios than Section 2 (Fig. 6).

Generally, Hf increases in the core to rim direction in the zircons from Section 2-4 and diagrams of $\mathrm{Hf}$ [ppm] versus other trace elements should approximate the magma evolution as plagiogranite melts crystallized. This is because Hf-rich zircon is stabilized at lower temperatures. The zircons from Section 2 have different trends in $\mathrm{Hf}$ versus trace elements diagrams to zircons 

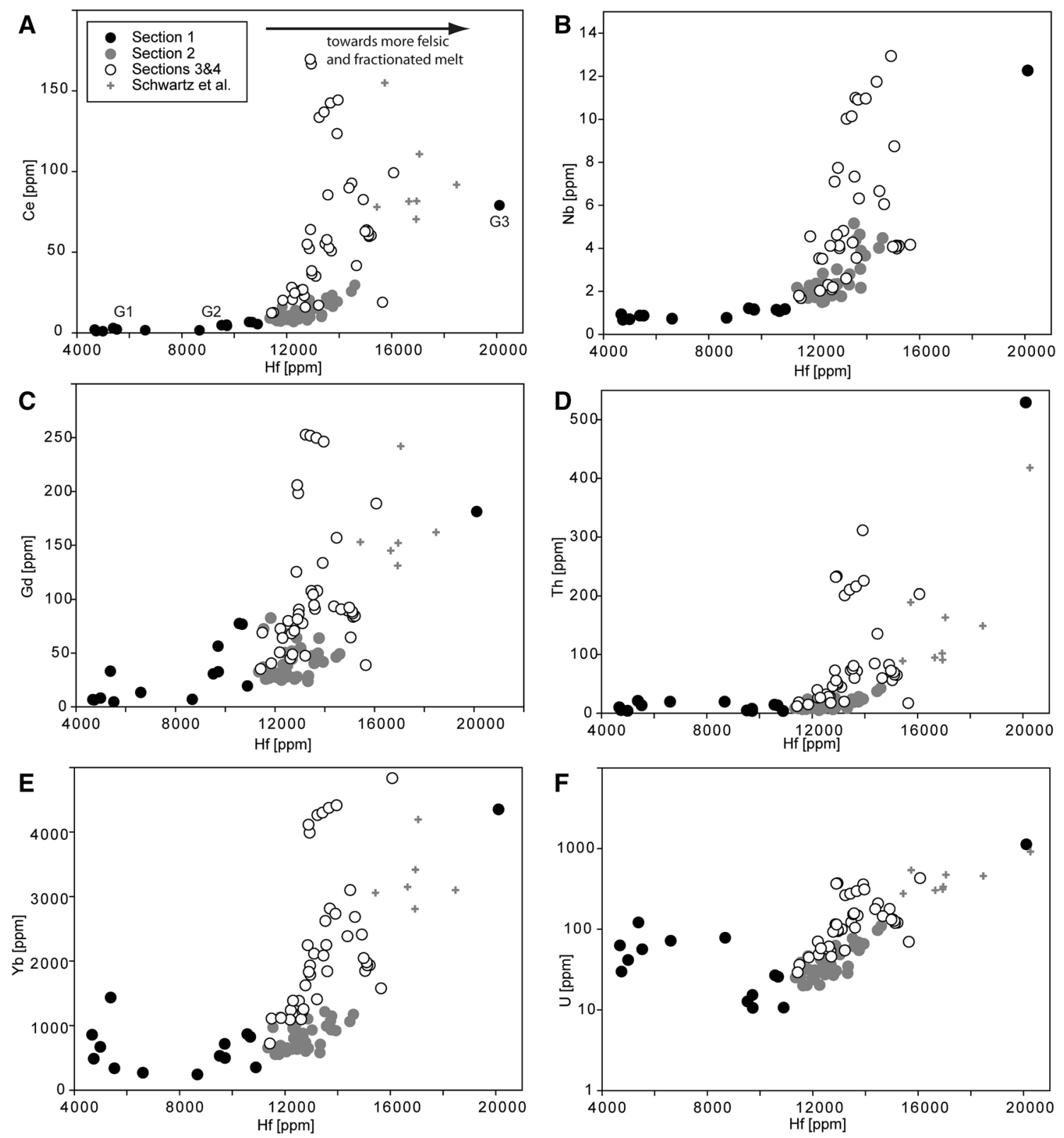

Fig. 7 Compositional trends for trace elements with increasing Hf in zircon. Since Hf generally increases in the core to rim direction (Fig. 3) the plot shows a possible record of changing zircon composition as magma evolved

from Sections 2 and 4 (Fig. 7). In detail, Section 2 zircons have only slightly increasing contents for many elements (Ce, HREE, Y, Th, U, Nb, Ta) with increasing Hf content or more random distribution for other elements (other LREE, MREE). In contrast, Sections 3 and 4 zircons have abrupt increases of these elements up to $c$. $14,000 \mathrm{ppm} \mathrm{Hf}$, which then decrease at higher Hf concentrations. Interestingly, similar trends were observed for natural whole rock compositions in $\mathrm{SiO}_{2}$ versus $\mathrm{REE}$ concentrations (Brophy 2009), where $\mathrm{SiO}_{2}$ should reflect magma evolution in a similar manner as $\mathrm{Hf}$ reflects it in zircon. For elemental ratios, trends are similar between
Sections 2, 3 and 4 with decrease in Eu anomaly and increase in $\mathrm{Yb} / \mathrm{Gd}$ ratio with increasing $\mathrm{Hf}$ (Fig. 4).

\section{Zircon: comparison with other datasets}

Trace elements were analysed in oceanic zircons from a few localities including over 30 analyses of zircon from ODP Site 735B (Grimes et al. 2009). Another dataset includes zircons from a felsic vein intruding oxide gabbro, the sample of which was dredged during Leg 31 (Schwartz et al. 2010). Generally, our analyses fit well with the database of Grimes et al. (2009) and usually plot in the middle of a 
cloud defined by magmatic zircon (Type 1 and 2, euhedral and subhedral to anhedral magmatic grains, respectively) in this database (Fig. 4). Trends defined by Site 735B zircon are usually tighter and better defined than the general trends; however, the direction of element versus element change is similar. Porous grains (Type 3-defined as hydrothermal grains in Grimes et al. 2009) are usually outside of the compositional range of zircons analysed in this study. The only group of zircons that is not within the compositional range of the dataset of Grimes et al. (2009) is Group 2 zircon from oxide gabbro (Fig. 4).

The zircon grains analysed in the sample described by Schwartz et al. (2010) usually plot outside the compositional fields defined by the zircon analysed in this study. Their Hf concentration is higher and also most of the trace element concentrations are higher or similar to the maximum values observed in zircon from Sections 3 and 4. In fact, the zircon composition seems to overlap partly only with the single grain constituting Group 3 in Section 1 (Fig. 4), which suggests that Group 3 is a separate and important group and not a single outlier.

\section{Discussion}

The felsic melts may form within oceanic crust either by extreme fractional crystallization of mafic melts (classical approach, e.g. Aldiss 1981) or by remelting of hydrated oceanic crust (e.g. Koepke et al. 2007). Also, the melts may be separated from their host rocks and may intrude into the overlying already frozen gabbroic crust as a system of thin veins redistributing incompatible elements during the process (Dick et al. 2000, 2016). As the chemical composition of the felsic veins is often affected by accumulation and hydrothermal alteration, zircon may preserve records of the processes responsible for felsic melt formation and evolution. Here we examine different aspects of felsic melt formation by interpreting trace element and isotope compositions of zircon.

\section{Oxide gabbro: diverse processes of felsic melt formation recorded in Groups 1 to 3 zircon}

A characteristic feature of the oceanic crust at Atlantis Bank is the presence of oxide gabbros with Fe-Ti oxide contents that may reach 5-30\%. Mineral assemblages of the oxide gabbros are not in equilibrium implying formation in at least two stages (Dick et al. 2000). In the first stage primitive gabbro cumulate is intruded by more evolved ferrous melt, which crystallizes and forms a second stage cumulate (Dick et al. 2002). In particular, Fe-Ti oxides crystallize from these evolved, late percolating melts (Dick et al. 2002). These melts could be derived from a fractionating gabbro pile below, or they could represent separated Ferich silicate melts formed by liquid immiscibility (Natland et al. 1991; Dick et al. 2000; Leader 2013). This complex origin of late melts in oxide gabbros is recorded also in zircons analysed in this study, as zircon forms three chemically distinct groups. We attribute the differences in zircon chemistry between the groups to different stages of oxide gabbro formation. In particular:

a. Group 1 zircon records high temperature crystallization in evolving melt derived from a source depleted in incompatible elements. These zircons have the highest Ti contents, which can be roughly related to temperatures of crystallization of approximately $800-870^{\circ} \mathrm{C}$ (depending on the Ti-activity assumed for calculations; Watson et al. 2006; Ferry and Watson 2007). These zircons could have been formed during primitive or oxide gabbro crystallization in intercumulus melt pockets. Interestingly, some trace elements vary strongly in the Group 1 zircons, but some are uniformly low. Variability of any trace element is the expected consequence of crystallization from a fractionating melt. On the other hand, low concentration and lack of variability suggests crystallization of another accessory mineral before zircon that impoverished the melt in some elements, in this case in $\mathrm{P}, \mathrm{Ce}, \mathrm{U}$ and $\mathrm{Th}$ as well as $\mathrm{Nb}$ and $\mathrm{Ta}$. Apatite is a common P-bearing mineral in Site 735B (Meurer and Natland 2001) and may also be enriched in Ce, $\mathrm{U}$ and Th. Therefore, it could be responsible for depleting evolving melt in these elements. However, $\mathrm{Nb}$ and $\mathrm{Ta}$ are compatible in Fe-Ti oxides such as ilmenite (Klemme et al. 2006) and low concentrations of these elements in zircon suggests that zircons from Group 1, but also Group 2 crystallized after massive crystallization of Fe-Ti oxides or were formed in silicic melts contemporaneous with immiscible ferrous ones. Alternatively, the melt was formed in a source already depleted in Ti-Fe rich melts. The latter may be envisaged as hydrous remelting of primitive gabbro from which oxide-rich melts were already removed. Other minerals that can impoverish melt in $\mathrm{Ti}, \mathrm{Nb}$ and $\mathrm{Ta}$ are titanite or rutile, however, rutile was not reported in oceanic crust and titanite would have caused $\mathrm{Nb} /$ Ta fractionation, which is not observed in Group 1 zircon (Ta has approximately three times higher partition coefficient than $\mathrm{Nb}$ in titanite, e.g. Green and Parsons, 1987). Regardless of the process, the implication is that group 1 zircon crystallization is closely connected to crystallization or escape of oxide-rich melts and shows that after formation of Ti-Fe rich melts the silicic melt was still present in the gabbroic crust and could evolve to produce plagiogranite (for details see the next section). 
b. Group 2 zircons record low temperature crystallization from melts depleted in incompatible elements and with unusual fractionation signals-melts formed by hydrous remelting. Zircons of Group 2 have compositions where all the elements, which were impoverished in Group 1 zircons, have even lower concentrations in Group 2. This indicates that apatite and Fe-Ti oxides or titanite crystallized before the formation of the melt from which Group 2 zircons crystallized (the presence of titanite is implied by high $\mathrm{Nb} / \mathrm{Ta}$ ratios in this group). Most interesting are low Hf and Ti concentrations, low negative Eu anomaly (0.4-0.8 compared to $0.1-0.3$ in other groups) and high $\mathrm{Yb} / \mathrm{Gd}$ ratios, and we suggest that these parameters record formation of felsic melts by hydrous partial melting. The debate on the origin of plagiogranite has focused recently on two possible scenarios: hydrous partial melting of oceanic crust versus extreme fractional crystallization. Both processes produce high $\mathrm{Si}$ melts, but partial melting produces melts with lower Ti (Koepke et al. 2007) and REE contents (Brophy 2009). Also, microstructural record in gabbros from Site 735 drilled during IODP Leg 176, particularly the formation of plagioclase strongly enriched in anorthite content at grain boundaries, indicates that felsic melts were produced during the late stage evolution by hydrous partial melting of just frozen cumulate rocks (Koepke et al. 2004; Wolff et al. 2013). Experimental results, simulating hydrous gabbro melting show that extreme modal changes occur over the first $10 \%$ of melting with plagioclase abundance decreasing by over $20 \%$ and that of amphibole increasing from 0 to $50 \%$ (Koepke et al. 2004). Such interplay between amphibole and plagioclase should be clearly recorded in the chemical composition of resulting melts and specifically in Eu anomalies and HREE/MREE ratios. Low negative Eu anomalies and high $\mathrm{Yb} / \mathrm{Gd}$ in Group 2 zircons could be a result of zircon crystallization in an early, low volume melt produced in the regime of plagioclase melting and amphibole crystallization. Therefore, Group 2 zircon could represent crystallization in melts formed by low volume, hydrous gabbro melting. As Group 1 zircons closely resemble Group 2 zircons for many elements, it may suggest that formation of their parental melts was also related and Group 1 zircons represent crystallization in melts produced by higher volumes of hydrous gabbro melting. One and probably the only way to distinguish between different scenarios of Group 1 zircon formation is to sample, identify and date the chemically diverse groups of zircon from oxide gabbros; a work for future study. c. Group 3 zircon crystallized in highly evolved melt produced by fractionation of mafic melts. This zircon has a different composition compared to Groups 1 and 2, and it also has the lowest $\delta^{18} \mathrm{O}$ of $3.5 \%$. In this study, the group is represented by a single grain, but grains of similar trace element composition were also sampled from a felsic vein crosscutting oxide gabbro (Schwartz et al. 2010) and they also occur in plagiogranite from lower Section 2, 3and 4. Extremely high concentration of Hf, P, Y, REE, Th and $\mathrm{U}$ as well as $\mathrm{Nb}$ and Ta are consistent with crystallization in highly evolved melts formed by fractional crystallization. In particular, REE concentrations should increase in silicic melts formed by fractional crystallization as compared to the melts formed by gabbro melting (Brophy 2009). However, recent experiments of Wolff et al. (2013) produced small amounts of unusually high $\mathrm{P}, \mathrm{Zr}$ and $\mathrm{Ti}$ melt, immiscible from the silicic melt. Such melt is expected to be rich both in incompatible elements and $\mathrm{Nb}$ and $\mathrm{Ta}$, and therefore, crystallization of the Group 3 zircon in such a melt cannot be excluded. These two different scenarios could be perhaps distinguished by careful, precise dating of zircon of known composition as fractional crystallization of the gabbro pile and its remelting could be potentially spaced in time. Schwartz et al. (2010) obtained old ages for zircons similar in composition to Group 3 zircon (12.46 Ma, therefore older than the assumed age of oceanic crust formation), which may suggest that they represent an early process of gabbro crystallization. Also, similar compositions of zircons from different depths may indicate that the zircons formed in early fractionated melts that travelled through the cumulate oceanic crust.

\section{Relationship between zircon in oxide gabbros and in felsic melts from deeper sections}

Grimes et al. (2009) showed that zircons from late stage assemblages in gabbros and plagiogranitic veins from slowspreading ridges have overlapping compositions for many trace elements and elemental ratios. The typical trend is decrease in $\mathrm{Ti}$ concentration in zircon without substantial change in other elements, followed by low variation in $\mathrm{Ti}$ accompanied by large variation in Hf and other incompatible elements. The first trend was observed mostly in zircons from gabbros, whereas the latter was in plagiogranites. The change from one trend to the other was interpreted to record change from (1) crystallization in a fractionating melt to (2) crystallization in melt whose composition was buffered by numerous major and accessory phases (Grimes et al. 2009). Similar trends are observed in this study, with Group 1 zircon from oxide gabbro recording crystallization with decreasing temperature and zircons from plagiogranite 
veins recording crystallization at constant temperature, probably from buffered, late stage melts. The buffering of melt composition by different phases during plagiogranite crystallization is also recorded in low variations in elemental ratios, such as Eu anomaly (controlled by plagioclase), $\mathrm{Yb} / \mathrm{Gd}$ (controlled by amphibole, clinopyroxene or apatite) or $\mathrm{Nb} / \mathrm{Ta}$ (controlled by titanite or Fe-Ti oxides).

The continuous trends in trace element against trace element diagrams, recorded in zircon in the study of Grimes et al. (2009), suggest continuous fractionation of melts with less evolved melts trapped in gabbros and more evolved melts forming plagiogranites. Interestingly, in this study zircons from oxide gabbro and plagiogranite do not overlap in composition. Despite that there seems to be a link between the composition of oxide gabbro zircons (Group 1) and plagiogranite zircons, as zircons with similar Hf content (9000-10,000 ppm in oxide gabbro and $10,000-11,000 \mathrm{ppm}$ in plagiogranite) have similar ranges of trace elements (Fig. 7). In detail, if an element has a low concentration and low variation in oxide gabbro (e.g. Nb, $\mathrm{Ce}, \mathrm{Yb}, \mathrm{Th}, \mathrm{U})$ it has similar low concentrations and low variability in plagiogranite zircons. Likewise, if the element is variable and has higher concentration in zircons from oxide gabbro, the same is observed in plagiogranite zircons (Fig. 7). This continuity in trace element composition of zircon is better observed in oxide gabbro and zircon from plagiogranite from Section 2, which has lower REE, $\mathrm{U}$ and $\mathrm{P}$ concentrations compared to zircon from Sections 3 and 4 , and therefore, is more similar to Group 1 zircon from oxide gabbro. This may indicate that melts crystallizing zircon in both oxide gabbro and Section 2 plagiogranite may have been derived from a similar source, for example an evolving gabbro pile. In that context melts from oxide gabbro (Group 1) would have been less evolved and have had a higher temperature of crystallization than the plagiogranitic melts.

\section{Processes responsible for $\mathrm{O}$ isotope variations}

The fractionation of $\mathrm{O}$ isotopes between zircon and silicate melt is fairly well established and generally $\delta^{18} \mathrm{O}$ in zircon should not vary with melt fractionation (e.g. Trail et al. 2009). Most oceanic zircons have uniform $\delta^{18} \mathrm{O}$ of $5.2 \pm 0.5 \%$ o in equilibrium with the mantle-derived melts (Grimes et al. 2011), suggesting that felsic oceanic melts crystallizing zircon evolve by simple fractional crystallization. In our study, the range of $\delta^{18} \mathrm{O}$ is larger, from 3.5 to $6.0 \%$, with plagiogranite zircons having an average mantle-like $\delta^{18} \mathrm{O}$ value of $5.2 \pm 0.5 \%$ o (i.e. identical to the Grimes et al. 2011 average). In contrast, zircons from oxide gabbro have a lower average $\delta^{18} \mathrm{O}$ of $4.3 \pm 0.4 \%$. Also, in plagiogranites, the distribution of $\delta^{18} \mathrm{O}$ is not uniform and Section 3 seems to have lower $\delta^{18} \mathrm{O}$ compared to Section 2 and 4. These low $\delta^{18} \mathrm{O}$ zircons could not crystallize from a mantle-derived melt and require additional processes of $\mathrm{O}$ isotope fractionation occurring within the oceanic crust.

Values of $\delta^{18} \mathrm{O}$ lower than $5.0 \%$ in zircon are consistent with derivation of melts by partial melting of a hydrothermally altered source (e.g. Schmitt and Vazquez 2006; Bindeman 2008). In particular, the lower values are the result of hydrothermal alteration of oceanic crust at temperatures above $200^{\circ} \mathrm{C}$. However, the zircon from Section 1 Group 2, which has a clear trace element record of crystallization in melts formed by such melting, also has the highest $\delta^{18} \mathrm{O}$ of all of the zircons in oxide gabbro $\left(4.5-5.0 \%\right.$ ). On the other hand, the lowest $\delta^{18} \mathrm{O}$ values are in zircons with high trace element concentrations (Group 3 Sections 1,3), which we attribute to fractionation of restitic melt in the gabbro pile and not to remelting. Therefore, low $\delta^{18} \mathrm{O}$ in oceanic zircon cannot be explained purely by hydrous remelting, but also $\delta^{18} \mathrm{O}$ in the range $4.5-5.0 \%$ or higher does not contradict that such melting happened. In detail, because of the shallow pressure, the amount of water needed to produce hydrous partial melting could be very low (e.g. less than $3 \mathrm{wt} \%$ for water saturation in basalts at $2 \mathrm{~kb}$, Berndt et al. 2002), resulting in very low water/rock ratios (e.g. less than 0.03), making it very hard to detect any seawater influence by isotopic means. Also, in gabbros drilled at ODP Site 735 , the $\delta^{18} \mathrm{O}$ variation with depth is complex and never reaches values below 5\%o. The upper $800 \mathrm{~m}$ of gabbro have depleted $\delta^{18} \mathrm{O}($ c. $5.1 \%$ ) values and the lower $700 \mathrm{~m}$ have mostly enriched $\delta^{18} \mathrm{O}$ values $(6-7 \%$; Alt and Bach 2006; Gao et al. 2006), so the remelting of this crust could not produce low $\delta^{18} \mathrm{O}$ melts.

Another way to fractionate oxygen isotopes is liquid immiscibility with silica-rich liquids having $\delta^{18} \mathrm{O}$ higher by up to $1 \%$ o than coexisting Fe-rich liquids (Kyser et al. 1998; Lester et al. 2013). Since we observe lower $\delta^{18} \mathrm{O}$ than those in equilibrium with mantle melts rather than higher, they could have not been produced by fractionation between immiscible melts.

Finally, large $\delta^{18} \mathrm{O}$ redistribution may happen due to diffusion in response to a thermal gradient ( $\mathrm{Li}$ and $\mathrm{Liu}$ 2015). In detail, in the water-rich environment mass dependent $\mathrm{O}$ isotope fractionation occurs with light $\mathrm{O}$ isotopes moving towards the high temperature region (Bindeman et al. 2013; $\mathrm{Li}$ and Liu 2015). In that context, we can envisage that such gradients existed within the oceanic crust. For example, low $\delta^{18} \mathrm{O}(<5.2 \% o)$ is mostly confined to chemically variable zircon from oxide gabbro, suggesting that redistribution of $\mathrm{O}$ isotopes occurred after melts were emplaced in the oxide gabbro. Taking that into account we suggest that perhaps the oxide gabbro section acted as a hot zone due to longer crystallization and higher contents of evolved melts. Such conditions would trigger redistribution of $\delta^{18} \mathrm{O}$ in a thermal gradient, similar to that observed in the Bindeman 
et al. (2013) experiments. What may be important here is the sequence in time when separate melts arrived into such a hot zone: (1) early melts represented by Group 3 zircon intruded the oxide gabbro when the temperature was the highest and the redistribution of $\mathrm{O}$ isotopes could be the most extensive, (2) melts that crystallized Group 1 zircons were intruded later, when temperature was lower and the redistribution was less pronounced, and (3) low temperature melts crystallizing Group 1 zircons were almost not affected by $\delta^{18} \mathrm{O}$ redistribution. Generally, the results show that more data on fractionation of $\mathrm{O}$ isotopes are needed to understand their variation in some environments. Interestingly, the zircon record from oxide gabbro offers the most insight into the late-magmatic to post-magmatic processes in the oceanic crust. This is perhaps because the thick zone of the most evolved oxide gabbro crystallized over a longer time span or was injected by variable melts several times during oceanic crust formation and evolution.

\section{Different origin of plagiogranites at c. $500 \mathrm{~m}$ b.s.f. and c. $900 \mathrm{~m}$ b.s.f.}

The composition of zircons in Section 2 (c. $500 \mathrm{~m}$ b.s.f.) and Sections 3 and 4 (850-940 m b.s.f.) is different with the latter including zircons with several times higher concentrations of many trace elements. Also, zircons from Sections 2, 3 and 4 plot differently in Hf versus other elements diagrams (Fig. 7). Hafnium content in oceanic zircon should increase with increasing melt evolution and $\mathrm{Hf}$ is usually well correlated with decreasing Ti content; therefore, decreasing temperature (Watson et al. 2006) both in continental (Clairborne et al. 2006) and oceanic environments (Grimes et al. 2009). Thus, increasing Hf in zircon can be roughly related to increasing $\mathrm{Si}$ content in the surrounding melt. Section 2 zircons show slightly increasing concentrations of incompatible elements only at the very late stage for the highest $\mathrm{Hf}$ concentrations. On the other hand, zircons from Sections 3 and 4 have very rapid increases in most trace elements with increasing Hf. The enrichment factor, calculated as the averages of Sections 3 and 4 zircon compositions divided by the average Section 2 zircon composition varies from 2.2 to 2.4 (for Ta, MREE and P) to 3.6-4.8 (for LREE and Th). Interestingly, the two different trends observed in Sections 2, 3 and 4 mimic trends observed for plagiogranite whole rock compositions with increasing silica content (Brophy 2009). Rapid increase in the most incompatible elements, especially LREE, is expected in a melt evolving by fractional crystallization of basaltic magma (Brophy 2009), and that is what is also observed in Sections 3 and 4. On the other hand, slight changes in the incompatible elements with increasing silica was attributed to melts formed by hydrous partial melting of oceanic crust and this pattern is similar to that observed for trace elements versus Hf for Section 2 zircons (Fig. 7). Another parameter of plagiogranites formed by hydrous gabbro melting is inherently low Ti content caused by prior removal of Ti-rich melts (Koepke et al. 2007). Tirich melt would have been also enriched in $\mathrm{Nb}$ and $\mathrm{Ta}$, the elements which are lower in Section 2 zircon compared to Sections 3 and 4 zircon. Therefore, we conclude that plagiogranite from Section 2 could be a result of hydrous partial melting and plagiogranite from Sections 3 and 4 formed by fractional crystallization of intercumulus melts. The difference in the magma evolution trends between hydrous melting and fractional crystallization is the result of early amphibole crystallization in the restite after hydrous melting (Koepke et al. 2007; Brophy 2009), whereas amphibole appears late during basaltic magma fractionation. Another test that should distinguish amphibole-present from amphibole-absent conditions is the shape of the $\mathrm{Nb}$ versus Hf trend. Niobium is more compatible in amphibole than in any other major phase, which may constitute part of a cumulate or restite assemblage (GERM database). Therefore, similar to REE, a substantial increase in $\mathrm{Nb}$ with increasing $\mathrm{Hf}$ is expected if amphibole is absent, and that is observed in zircons from Sections 3 and 4. In contrast, $\mathrm{Nb}$ should not increase much when amphibole remains as a restitic mineral and that is observed in Section 2 zircons. Therefore, $\mathrm{Nb}$ variations confirm that two different processes are responsible for plagiogranite formation, i.e. hydrous melting for Section 2 and fractional crystallization for Sections 3 and 4.

\section{Melt compositions at different depths}

Isotope melt composition is recorded in $\varepsilon \mathrm{Hf}$ of zircon, which can be directly related to the Hf isotope composition of mantle-derived magmas forming the crustal pile. In our study ranges of $\varepsilon \mathrm{Hf}$ mostly overlap, although a larger spread in values, as well as lower values, occurs in Sections 3 and 4, compared to Sections 1 and 2. This may imply slightly different isotope compositions of the mantle source and more depleted mantle for the upper $0.5 \mathrm{~km}$ of the oceanic pile compared to the lower depths. Alternatively, low variabilty in Hf isotope values in the upper section may be linked to the process of remelting that homogenized previously more variable isotope compositions.

Trace element melt composition in equilibrium with zircon can be calculated based on known partition coefficients (Sano et al. 2002) and is another way to illustrate differences between different sections of oceanic crust at Site 735B. Reconstructed REE contents of melts from Sections 1 and 2 are different from both the measured, whole rock, plagiogranite REEs and MOR basalts (Fig. 8a). On the other hand, reconstructed melts from Sections 3 and 4 overlap with the whole rock plagioclase compositions 
(Fig. 8b). The latter have typical REE patterns of fractionated melts, which is consistent with zircon crystallizing in felsic melts evolving by extreme fractional crystallization. In contrast, low REE contents, the concave down pattern and positive Eu anomaly observed in Section 1 reconstructed melts are consistent with partial melting of REE impoverished source such as gabbro cumulate. The reconstructed melts from Section 2 have higher LREE contents, but not $\mathrm{Ce}$ and HREE, indicating perhaps more fractionated melts derived from a similar source to Section 1 melts or more intense melting of LREE-bearing phases e.g. apatite, which initially remained in the restite. Low reconstructed Ce concentration in the melt for both Sections 1 and 2 also indicates different redox conditions in the lower and upper parts of the oceanic crust. Reduced conditions (low concentration of $\mathrm{Ce}^{+4}$ ) for felsic melts formed above $0.5 \mathrm{~km}$ (Sections 1 and 2) can be explained by low rock to water ratios during the gabbro remelting, the conditions suggested also by $\mathrm{O}$ isotopes in zircon. Altogether, the composition of reconstructed melts is consistent with different processes governing the formation of the majority of plagiogranitic melts in upper and lower ocean crust sections in ODP Site $735 \mathrm{~B}$.

\section{Model of felsic melt formation in slow-spreading oceanic crust}

Our proposed model suggests that felsic melts in oceanic crust were formed in two processes by fractional crystallization of mafic melts and by hydrous remelting of the cumulate gabbro pile (Fig. 9). The melts formed by fractional crystallization dominate in the lower section (below $0.5 \mathrm{~km}$ ) but are present also in the upper section (above $0.5 \mathrm{~km}$ ). We assume that after formation such melt could travel upwards, intrude the overlying gabbro pile and crystallize zircon at different stages of melt fractionation (Fig. 9). Depending on the local thermal conditions in the oceanic pile the melts could have been affected by redistribution of $\mathrm{O}$ isotopes in a thermal gradient. Therefore, the $\delta^{18} \mathrm{O}$ below $5.2 \pm 0.2 \%$ in these melts are due to thermal redistribution and not due to remelting of hydrothermally altered oceanic crust. As such, the source of water for the melting is unknown and could be seawater and/or fluids derived from the oceanic crust crystallization. However, since the records of hydrous partial melting are limited to the upper $500 \mathrm{~m}$ of the Site 735B section, it favours seawater as the possible trigger of hydrous partial melting (Fig. 9).

The ages of the two stages could be tentatively related to the ${ }^{206} \mathrm{~Pb} /{ }^{238} \mathrm{U}$ zircon ages of Schwartz et al. (2010). Zircons with high incompatible element contents are old $(12.76 \pm 0.2 \mathrm{Ma})$ and are similar in composition to the zircons from Sections 3 and 4 and scarce zircons from the

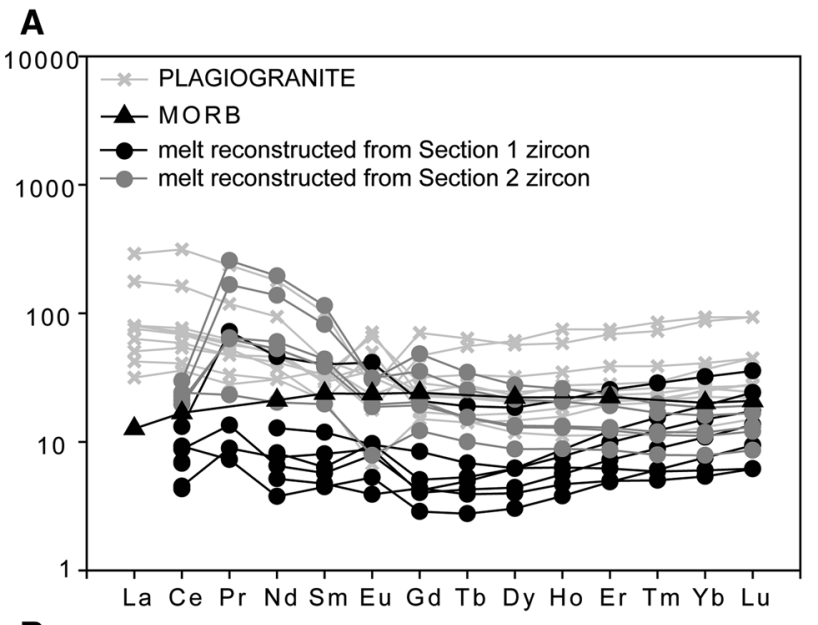

B

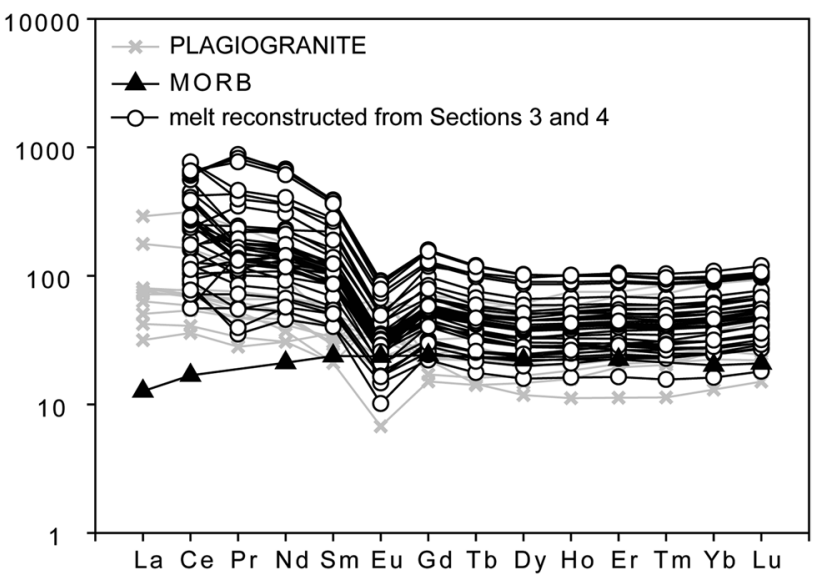

Fig. 8 Reconstructed melt REE patterns using partition coefficients between plagioclase and melt of Sano et al. (2002). Plagiogranite rock compositions from IODP Site $735 \mathrm{~B}$ are from Robinson et al. (2002) and the basalt composition is from the GERM database

upper sections. Therefore, the age of the extreme fractionation of the melts represented by the zircons can be placed at $12.76 \pm 0.2 \mathrm{Ma}$. The hydrothermally altered zircons dated by Schwartz et al. (2010) are $12.0 \pm 0.16 \mathrm{Ma}$ and can be related to hydrothermal alteration and fluid movement through the crustal pile. We conclude that the same process could be also responsible for wet partial melting at lower depths, and therefore, at higher temperatures, which probably characterized Sections 1 and 2 (Fig. 9).

\section{Conclusions}

The analysed zircons from four depth sections in IODP Site $735 \mathrm{~B}$ have variable trace element and $\delta^{18} \mathrm{O}$ compositions and rather uniform $\varepsilon \mathrm{Hf}$, suggesting that (1) magmas forming the oceanic crust section were derived from an isotopically homogenous source, but (2) diverse processes were 
responsible for the formation of felsic melts, which resulted in variability in trace elements and $\delta^{18} \mathrm{O}$ in zircons.

The processes can be grouped in two stages: (1) the presumably older one is consistent with formation of fractionated melts; these processes are represented by felsic veins and zircons from deeper Sections 3 and 4, and scarce zircon grains in Sections 1 and 2-this stage could be contemporaneous with formation of Fe-rich melts; (2) the younger one is consistent with several episodes of hydrous remelting of cumulate gabbro; these processes are represented by felsic veins and zircons from upper Sections 1 and 2-this stage postdates formation of Fe-rich melts and melting affected a source, which was already impoverished in elements compatible in Fe-Ti oxides.

Our study shows that chemical diversity of oceanic zircon can be linked to different processes of felsic melt formation and distribution through the oceanic crust. The study of zircon offers insight into how different incompatible elements were mobilized, and since chemically distinct zircons can be targeted for dating, what the time-frame was for elemental redistribution. Also, zircon provides information on the processes that occurred close to the
A IODPHole735B
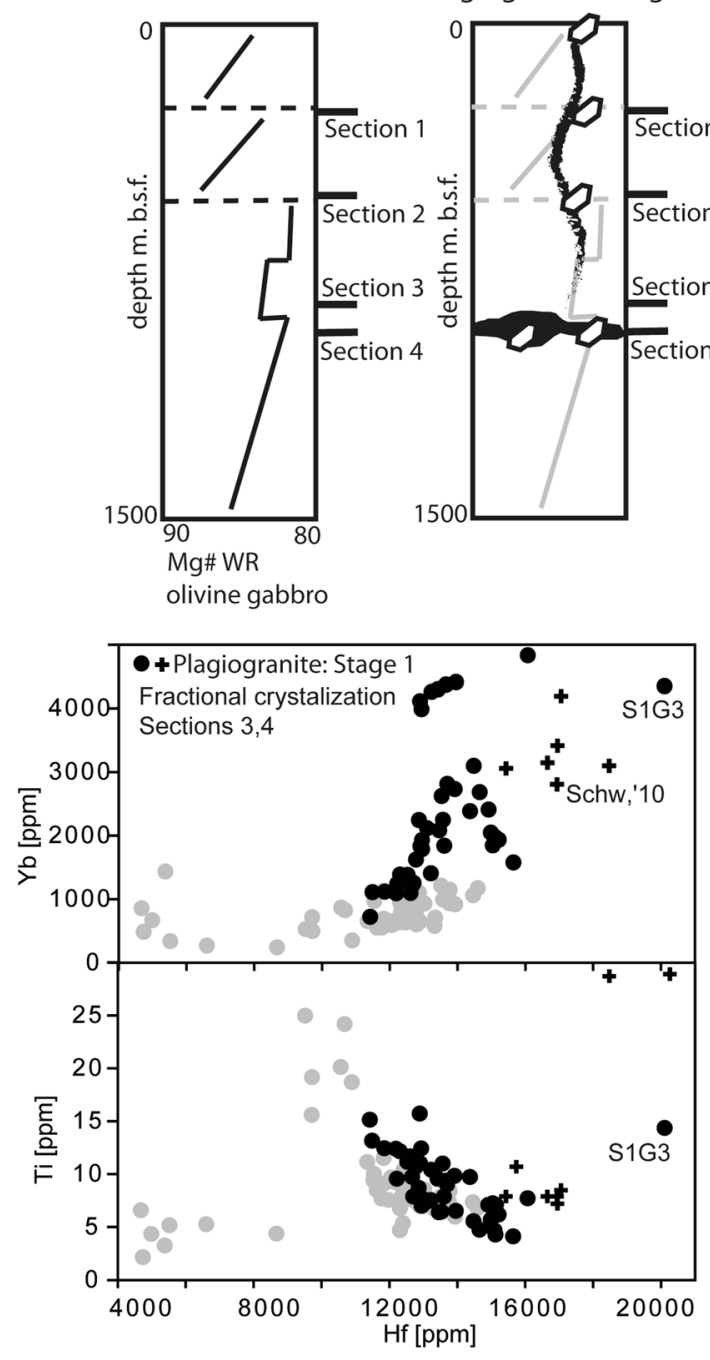

Fig. 9 Formation of plagiogranite melts in two stages shown in the schematic section through the oceanic crust at the IODP Site $735 \mathrm{~B}$ (the section modified after Natland and Dick 2002a). Stage 1 includes formation and distribution of felsic melts by fractional crystallization, the melt's distribution is shown in black and possible depths of zircon crystallization are marked with zircon shaped symbols. Stage 2 includes formation of felsic melts by hydrous partial melt-

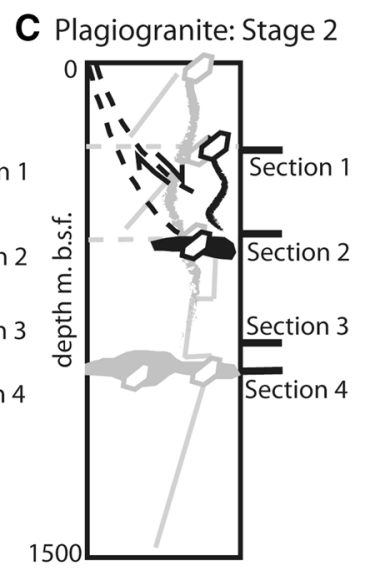

STAGE 1

(I) formation and migration of differentiated melts by fractional crystallization

(II) plagiogranites formed mostly in Sections 3 and 4

(III) estimated age ca. $12.76 \mathrm{Ma}$ age of crust formation by magma pulses (Schwartz et al. 2010)

\section{STAGE 2}

(I) formation of detachement faults, uplift and deformation of the crust possible ingress of seawater in the upper part of the crust (II) plagiogranites formed in Sections 1 and 2 (III) estimated age ca. 12.0 Ma age of hydrothermal alteration (Schwartz et al. 2010)

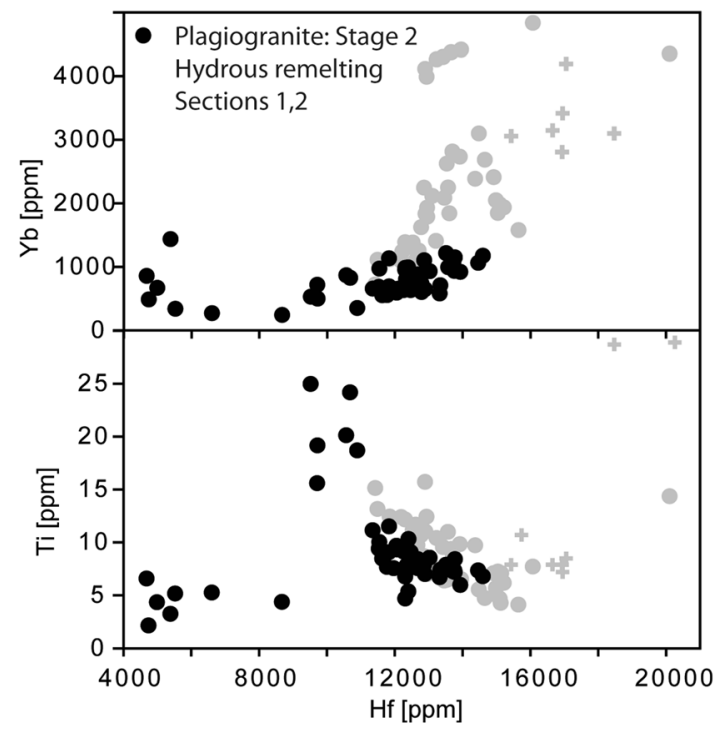

ing, the melts dominate in the upper part of the oceanic section and are related to the crustal uplift via detachment faults (dashed lines). The chemical composition of zircon formed in each stage is shown below the schematic sections. Symbols in black show zircon crystallized during each stage. Stage 1 is represented mostly by zircon from Sections 3 and 4, but also by that from Group 3 Section 1 (S1G3) and 12.76 Ma zircons from Schwartz et al. (2010)—Schw.'10 
subsolidus and the magmatic/hydrothermal boundary and can clearly separate the elemental changes related to those two environments.

Acknowledgements Rafał Tyszka and Elżbieta Słodczyk help with data collection is greatly appreciated. The project was funded by a grant no. 1017/S/ING/15-I. Three reviewers are thanked for insightful comments.

Open Access This article is distributed under the terms of the Creative Commons Attribution 4.0 International License (http:// creativecommons.org/licenses/by/4.0/), which permits unrestricted use, distribution, and reproduction in any medium, provided you give appropriate credit to the original author(s) and the source, provide a link to the Creative Commons license, and indicate if changes were made.

\section{References}

Aldiss DT (1981) Plagiogranites from the ocean crust and ophiolites. Nature 289:577-578. doi:10.1038/289577a0

Alt JC, Bach W (2006) Oxygen isotope composition of a section of lower oceanic crust, ODP Hole 735B. Geochem Geophys Geosyst 7:Q12008. doi:10.1029/2006GC00138

Berndt J, Liebske C, Holtz F et al (2002) A combined rapid-quench and H2-membrane setup for internally heated pressure vessels: Description and application for water solubility in basaltic melts. Am Mineral 87:1717-1726. doi:10.2138/am-2002-11-1222

Bindeman IN, Lundstrom CC, Bopp C et al (2013) Stable isotope fractionation by thermal diffusion through partially molten wet and dry silicate rocks. Earth Planet Sci Lett 365:51-62. doi:10.1016/j.eps1.2012.12.037

Bindeman IN (2008) Oxygen isotopes in mantle and crustal magmas as revealed by single crystal analysis. Rev Mineral Geochem 69:445-478.

Brophy JG (2009) $\mathrm{La}_{-} \mathrm{SiO}_{2}$ and $\mathrm{Yb}-\mathrm{SiO}_{2}$ systematics in midocean ridge magmas: implications for the origin of oceanic plagiogranite. Contrib Miner Pet 158:99-111. doi:10.1007/ s00410-008-0372-3

Canales JP, Detrick RS, Toomey DR et al (2003) Segment-scale variations in the crustal structure of 150-300 kyr old fast spreading oceanic crust (East Pacific Rise, 8 degrees 15 ' N-10 degrees 5 ' N) from wide-angle seismic refraction profiles. Geophys J Int 152:766-794.

Cannat M (1996) How thick is the magmatic crust at slow spreading oceanic ridges. J Geophys Res 101:2847-2857. doi:10.1029/95JB03116

Claiborne LL, Miller CF, Walker BA et al (2006) Tracking magmatic processes through $\mathrm{Zr} / \mathrm{Hf}$ ratios in rocks and $\mathrm{Hf}$ and $\mathrm{Ti}$ zoning in zircons: an example from the Spirit Mountain batholith, Nevada. Mineral Mag 70:517-543. doi:10.1180/0026461067050348

Coogan LA (2014) The lower oceanic crust; 2nd Edition. In: Turekian K, Holland HD (eds) Treatise on geochemistry. Elsevier, Amsterdam, pp 497-541

Dick HJB, Meyer PS, Bloomer SH et al (1991) Lithostratigraphic evolution of an in-situ section of oceanic layer 3. In: Von Herzen RP, Robinson, PT et al. (eds.) Proc of the ocean drilling program, scientific results, vol 118, pp 439-538.

Dick HJB, Natland JH, Miller DJ et al (1999) Proc of the ocean drilling program. Initial Rep 176:1-314.

Dick HJB, Natland JH, Alt JC et al (2000) A long in situ section of the lower ocean crust: results of ODP Leg 176 drilling at the Southwest Indian Ridge. Earth Planet Sci Lett 179:31-51
Dick HJB, Ozawa K, Meyer PS et al (2002) Primary silicate mineral chemistry of a $1.5-\mathrm{km}$ section of very slow spreading lower ocean crust: ODP Hole 735B, Southwest Indian Ridge. In: Natland JH, Dick HJB, Miller, DJ, Von Herzen RP (eds) Proc of the Ocean Drilling Program, Sci Res, vol 176, pp 1-60. doi:10.2973/odp.proc.sr.176.001.2002.

Dick HJB, Natland JH, Ildefonse B (2006) Past and future impact of deep drilling in the oceanic crust and mantle. Oceanography 19(4):72-80. doi:10.5670/oceanog.2006.06

Dick HJB, MacLeod CJ, Blum P et al (2016) Expedition 360 Preliminary Report: Southwest Indian Ridge lower crust and Moho. Int Ocean Discov Program. doi:10.14379/iodp. pr.360.2016

Ferry JM, Watson EB (2007) New thermodynamic models and revised calibrations for the Ti-in-zircon and Zr-in-rutile thermometers. Contrib Miner Petrol 154:429-437. doi:10.1007/ s00410-007-0201-0

Fisher RL, Sclater JG (1983) Tectonic evolution of the southwest Indian ocean since the mid-Cretaceous: plate motions and stability of the pole of Antarctica/Africa for at least 80 Myr. Geophys J R Astron Soc 73:553-576. doi:10.1111/j.1365-246X.1983. tb03330.x

Gao J, Hoefs J, Przybilla R et al (2006) A complete oxygen isotope profile through the lower oceanic crust, ODP Hole 735B. Chem Geol 233:217-234. doi:10.1016/j.chemgeo.2006.03.005

Godard M, Awaji S, Hansen H et al (2009) Geochemistry of a long insitu section of intrusive slow-spread oceanic lithosphere: Results from IODP Site U1309 (Atlantis Massif, 30 degrees N MidAtlantic-Ridge). Earth Planet Sci Lett 279:110-122

Gregory RT, Taylor HP Jr (1981) An oxygen-isotope profile in a section of Cretaceous oceanic crust, Samail ophiolite, Oman: Evidence for $\delta 180$ buffering of the oceans by deep (N5 km) seawater-hydrothermal circulation at mid-ocean ridges. J Geophys Res 86:2737-2755. doi:10.1029/JB086iB04p02737

Grimes CB, John BE, Cheadle MJ et al (2009) On the occurrence, trace element geochemistry, and crystallization history of zircon from in situ ocean lithosphere. Contrib Mineral Petrol 158:757783. doi:10.1007/s00410-009-0409-2

Grimes CB, Ushikubo T, John BE et al (2011) Uniformly mantle-like $\delta^{18} \mathrm{O}$ in zircons from oceanic plagiogranites and gabbros. Contrib Miner Petrol 161:13-33. doi:10.1007/s00410-010-0519-x

Grimes CB, Ushikubo T, Kozdon R et al (2013) Perspectives on the origin of plagiogranite in ophiolites from oxygen isotopes in zircon. Lithos 179:48-66. doi:10.1016/j.lithos.2013.07.026

Hertogen J, Emmermann R, Robinson PT et al (2002) Lithology, mineralogy, and geochemistry of the lower ocean crust, ODP Hole 735B, Southwest Indian Ridge. In: Natland JH, Dick HJB, Miller DJ, Von Herzen RP (eds.) Proceedings of the ocean drilling program, scientific results, College Station, TX (Ocean Drilling Program), vol 176, pp 1-82. doi:10.2973/odp.proc.sr.176.003.2002

Klein EM (2003) Geochemistry of the igneous oceanic crust. In: Rudnick RL (ed) The Crust. Treatise on Geochemistry. Elsevier-Pergamon, Oxford, pp 433-464

Klemme S, Günther D, Hametner K et al (2006) The partitioning of trace elements between ilmenite, ulvospinel, armalcolite and silicate melts with implications for the early differentiation of the moon. Chem Geol 234:251-263. doi:10.1016/j. chemgeo.2006.05.005

Koepke J, Feig ST, Snow J et al (2004) Petrogenesis of oceanic plagiogranites by partial melting of gabbros: an experimental study. Contrib Miner Petrol 146:414-432. doi:10.1007/ s00410-003-0511-9

Koepke J, Berndt J, Feig S et al (2007) The formation of SiO2-rich melts within the deep oceanic crust by hydrous partial melting of gabbros. Contrib Miner Petrol 153:67-84. doi:10.1007/ s00410-006-0135-y 
Kyser TK, Lesher CE, Walker D (1998) The effects of liquid immiscibility and thermal diffusion on oxygen isotopes in silicate liquids. Contrib Miner Petrol 3:373-381. doi:10.1007/s004100050459

Leader J (2013) Microstructural analysis of Hole 735B, Atlantis Bank, Southwest Indian Ridge: reevaluation of high temperature fabric development. PhD thesis, Texas Tech University, pp. 179

Lester GW, Kyser TK, Clark AH (2013) Oxygen isotope partitioning between immiscible silicate melts with $\mathrm{H}_{2} \mathrm{O}, \mathrm{P}$ and S. Geochim Cosmochim Ac 109:306-311. doi:10.1016/j.gca.2013.01.037

Li X, Liu Y (2015) A theoretical model of isotopic fractionation by thermal diffusion and its implementation on silicate melts. Geochim Cosmochim Ac 154:18-27. doi:10.1016/j.gca.2015.01.019

Meurer WP, Natland JH (2001) Apatite compositions from oceanic cumulates with implications for the evolution of mid-ocean ridge magmatic systems. J Vol Geotherm Res 110:281-298. doi:10.1016/S0377-0273(01)00214-1

Natland JH, Dick HJB (2001) Formation of the lower ocean crust and the crystallization of gabbroic cumulates at a very slowly spreading ridge. J Vol Geotherm Res 110:191-233. doi:10.1016/ S0377-0273(01)00211-6

Natland JH, Dick HJB (2002a) Stratigraphy and composition of gabbros drilled in Ocean Drilling Program Hole 735B, Southwest Indian Ridge: a synthesis of geochemical data. In: Natland, JH, Dick HJB, Miller DJ, Von Herzen RP (eds) Proc ODP, Sci. Results, pp 176.

Natland JH, Dick HJB (2002b) A brief narrative history of ODP Hole 735B. In: Natland, JH, Dick HJB, Miller DJ, Von Herzen RP (eds) Proc ODP, Sci. Results, pp 176.

Natland JH, Meyer PS, Dick HJB et al (1991) Magmatic oxides and sulfides in gabbroic rocks from ODP Hole $735 \mathrm{~B}$ and the later development of the liquid line of descent. In: Von Herzen RP, Robinson PT et al (eds) Proc. ODP, Sci. Results, vol 118, pp 41-73.

Niu Y, Gilmore T, Mackie S et al (2002) Mineral chemistry, wholerock compositions, and petrogenesis of Leg 176 gabbros: data and discussion. In: Natland, JH, Dick HJB, Miller DJ, Von Herzen RP (eds) Proc ODP, Sci. Results, pp 176.

Ozawa K, Meyer PS, Bloomer SH (1991) Mineralogy and textures of iron-titanium oxide gabbros and associated olivine gabbros from hole 735B. In: Von Herzen RP, Robinson PT et al (eds) Proc ODP, sci. results, pp 118.

Robinson PT, Erzinger J, Emmermann R (2002) The composition and origin of igneous and hyrothermal veins in the lower ocean crust-ODP Hole 735B, Southwest Indian Ridge. In: Natland, JH, Dick HJB, Miller DJ, Von Herzen RP (eds) Proc ODP, Sci. Results, pp 176.

Sano Y, Terada K, Fukuoka T (2002) High mass resolution ion micropobe analysis of rare earth elements in silicate glass, apatite and zircon: Lack of matrix dependency. Chem Geol 184(3):217-230. doi:10.1016/S0009-2541(01)00366-7

Schmitt AK, Vazquez JA (2006) Alteration and remelting of nascent oceanic crust during continental rupture: Evidence from zircon geochemistry of rhyolites and xenoliths from the Salton Trough, California. Earth Planet Sci Lett 252:260-274. doi:10.1016/j. eps1.2006.09.041

Schwartz JJ, John BE, Cheadle MJ et al (2010) Dissolution-reprecipitation of igneous zircon in mid-ocean ridge gabbro, Atlantis Bank, Southwest Indian Ridge. Chem Geol 274:68-81. doi:10.1016/j.chemgeo.2010.03.017

Spulber SD, Rutherford MJ (1983) The origin of rhyolite and plagiogranite in oceanic crust; an experimental study. J Petrol 24:125. doi:10.1093/petrology/24.1.1

Trail D, B IN, deman IN, Watson EB et al (2009) Experimental calibration of oxygen isotope fractionation between quartz and zircon. Geochim Cosmochim Ac 73:7110-7126. doi:10.1016/j. gca.2009.08.024

Valley JW, Lackey JS, Cavosie AJ et al (2005) 4.4 billion years of crustal maturation: oxygen isotope ratios of magmatic zircon. Contrib Mineral Petrol 150:561-580. doi:10.1007/ s00410-005-0025-8

Watson EB, Wark DA, Thomas JB (2006) Crystallization thermometers for zircon and rutile. Contrib Mineral Petrol 151:413-433. doi:10.1007/s00410-006-0068-5

Wolff PE, Koepke J, Feig S (2013) The reaction mechanism of fluidinduced partial melting of gabbro in the oceanic crust. Eur $\mathbf{J}$ Miner 25:279-298. doi:10.1127/0935-1221/2013/0025-2314 